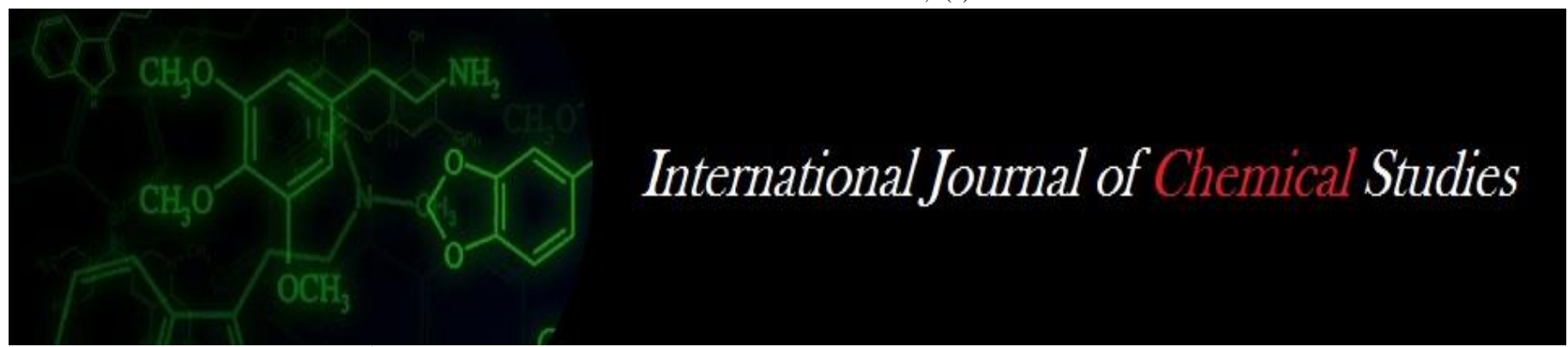

P-ISSN: 2349-8528

E-ISSN: 2321-4902

www.chemijournal.com

IJCS 2020; 8(2): 101-103

(C) 2020 IJCS

Received: 14-01-2020

Accepted: 17-02-2020

Archana Yadav

Ph.D., Research Scholar,

LPM Division, ICAR-NDRI,

Karnal, Haryana, India

Ramesh Chandra

Senior Scientist, LPM Division,

ICAR-NDRI, Karnal, Haryana,

India

Dang AK

Principle Scientist, Animal

Physiology Division, ICAR-

NDRI, Karnal, Haryana, India

Kuladip Prakash Shinde

Assistant Professor, Animal

Production, KVK, Sri

Ganganagar, SKRAU, Bikaner,

Rajasthan, India

Shailesh Kumar Gupta

Assistant Professor, LPM, CARS

Kunkuri, Jahspur, IGKV,

Chhattisgarh, India

Deepanshu Gupta

Ph.D. Research Scholar,

Physiology Division, ICAR-

IVRI, Bareilly, Uttar Pradesh,

India

Anup K Singh

Ph.D., Research Scholar, LPM

Division, ICAR-NDRI, Karnal,

Haryana, India

Mamta Singh

Assistant Professor, LPM,

DUVASU, Mathura, Uttar

Pradesh, India

Manish Ahirwar

Ph.D., Research Scholar, LPM

Division, ICAR-NDRI, Karnal,

Haryana, India

Corresponding Author:

Archana Yadav

Ph.D., Research Scholar, LPM

Division, ICAR-NDRI, Karnal,

Haryana, India

\section{Effect of polyherbal mixture supplementation during transition period on colostrum production and somatic cell counts of Sahiwal cows}

\author{
Archana Yadav, Ramesh Chandra, Dang AK, Kuladip Prakash Shinde, \\ Shailesh Kumar Gupta, Deepanshu Gupta, Anup K Singh, Mamta Singh \\ and Manish Ahirwar
}

DOI: https://doi.org/10.22271/chemi.2020.v8.i2b.8749

\begin{abstract}
The present investigation was conducted at LRC, ICAR-NDRI, Karnal to find out the effect of polyherbal mixture supplementation on colostrum production and SCC of the Sahiwal cows during the transition period. For that 32 multiparous Sahiwal cows were selected and divided into four groups, eight cows in each group. Control ( $\left.\mathrm{T}_{0}\right)$ group of cows were offered the ration as per the standard feeding schedule (NRC, 2001). The treatments group $\left(\mathrm{T}_{1}, \mathrm{~T}_{2}\right.$ and $\left.\mathrm{T}_{3}\right)$ cows were offered the same ration and with additionally in $\mathrm{T}_{1}$ group $200 \mathrm{~g}$ poly-herbal (50 g each Shatavari, Methi and Jeera; $25 \mathrm{~g}$ each Dalchini and Tulsi; added with $250 \mathrm{~g}$ jaggery) mixture was offered for 30 days before and 60 days after calving and in $\mathrm{T}_{2}$ group $150 \mathrm{~g}$ poly-herbal ( $25 \mathrm{~g}$ each Ajwain, Fennel, Ginger, Black cardamom and Black seeds, $20 \mathrm{~g}$ Turmeric and $5 \mathrm{~g}$ Clove; boiled with $25 \mathrm{~g}$ Black salt and jaggery) mixture was offered from parturition to 7 days postpartum and in $T_{3}$ group the poly-herbal mixture combination was given as a treatment. The colostrum yield and SCC of Sahiwal cows were recorded on $1^{\text {st }}, 3^{\text {rd }}$ and $5^{\text {th }}$ day after calving. The analysis of variance of data revealed that, the cows of $\mathrm{T}_{1}, \mathrm{~T}_{2}$ and $\mathrm{T}_{3}$ groups had significantly $(P \leq 0.05)$ higher colostrum yield on $5^{\text {th }}$ day. The SCC of colostrum was lower $(P \leq 0.05)$ at $5^{\text {th }}$ day in $\mathrm{T}_{3}$ followed by $\mathrm{T}_{1}, \mathrm{~T}_{2}$ and $\mathrm{T}_{0}$ groups of Sahiwal cows. The combination of poly-herbal supplementation had better effect on the colostrum production and quality of the Sahiwal cows during the transition period.
\end{abstract}

Keywords: Transition period, poly herbal mixture, colostrum yield, Colostrum SCC, Sahiwal cow

\section{Introduction}

India is leading country in milk production worldwide. For this the National Dairy Plan-I (NDP-I) has been launched by the government of India (GOI) with the aim to double milk production in the country by 2020 . In relation to the milk production growth rate, our demand (6-8\%) for milk is also increasing continuously. Milk is an important component of diets for all humans especially for vegetarians, as it is high in essential amino acids that are most likely to be deficient in diets based on vegetable protein. At present the milk production is 176.3 million tonnes with $375 \mathrm{gm} / \mathrm{d}$ per capita availability of milk (dahd.nic.in, 2017-18) and contributing $4.11 \%$ to GDP. Our country owns 192.49 million of total cattle population that contributes $35.94 \%$ of the total livestock (2019 Livestock census). Due to inferior usage of breeds and lack of availability of balance feed to animals, we could not able to fulfil our country's demand.

The population of Sahiwal cattle in the country is nearly 2.75 million (GoP, 2006) ${ }^{[8]}$. Because they are well known for disease resistance, heat tolerance and bred naturally (Leroy and Marchot, 1987) ${ }^{[14]}$. The demand of indigenous cow's milk increasing day by day due to the good quality protein. Milk from the Sahiwal breed (Bos indicus) is of $\mathrm{A}_{2}$ variety, with the best Beta Casein protein and 22 soluble minerals. It is non-allergic, need not be skimmed, as the fat is digestible and stays good for seven hours. Indigenous cows are also called farmer's friend (Chauhan, 2007) ${ }^{[4]}$.

But our indigenous cattle faced discrimination due to their low milk productivity and short lactation period. This problem can be minimized by giving more attention during transition period. 
Transition phase is most important, challenging and critical period in relation to the dairy cow's health status during the lactation cycle, defined as the period between three weeks before to three weeks after parturition (Drackley, 1999) ${ }^{[7]}$. To ensure more net return and to minimize high expenditure on feed are the main challenges, for which many research strategies have been practiced such as introducing feed supplements and feed additives (Pervez, 1992) [15]. Supplementation of spices and herbs having oxidative potential (Hui, 1996) ${ }^{[11]}$, antimicrobial activity (Dorman and Deans, 2000) [6], enhancing digestion by stimulating endogenous enzymes (Brugalli, 2003) ${ }^{[3]}$.

Keeping in view the above-mentioned fact, an alternative approach toward potentiating the colostrum production performance of Sahiwal cow with the use of natural ingredients will not only solve these problems but also ensure general wellbeing of cows and consequently will help to increase the functional life of cow and her progeny performance.

\section{Materials and Methods}

The study was conducted at the Livestock Research Centre, National Dairy Research Institute (NDRI), Karnal, India which is located at $29^{\circ} 42^{\prime \prime} 20 \mathrm{sec} \mathrm{N}$ and $76^{\circ} 58^{\prime \prime} 52.5 \mathrm{sec} \mathrm{E}$ at an altitude of 834 feet above mean sea level. Minimum and maximum ambient temperature ranged from near freezing point in winter to $45^{\circ} \mathrm{C}$ in summer with an annual rainfall of $700 \mathrm{~mm}$. The experiment was conducted during February, 2017 to end of November, 2017 with daily minimum and maximum temperature averaging $5.6{ }^{\circ} \mathrm{C}$ and $40{ }^{\circ} \mathrm{C}$, respectively. The sample analysis was done in Feed Processing and Quality Control Laboratory and Precision Instrument Laboratory of Dairy Cattle Nutrition Division, NDRI, Karnal.

This study was conducted after getting approval from the Research Committee and Institutional Animal Ethics Committee of ICAR - National Dairy Research Institute, Karnal, Haryana, India, the experiment was approved by the Institutional Animal Ethical Committee National Dairy (IAEC) of Indian Council of Agricultural Research (ICAR) National Dairy Research Institute (NDRI) constituted as per article 13 of the CPCSEA rules, laid down by the Govt. of India (Regd no-1705/GO/al/13 CPCSEA) dated 3/7/2013 A the ethical guidelines were followed during the course of the experiment.

The experiment was carried out to study the effect of polyherbal mixture in transition Sahiwal cows. Thirty-two pregnant dairy cows in second to fifth lactation with most probable production ability (MPPA) of around 2000-2500 L milk production were selected from the herd, maintained at Cattle Yard, NDRI, Karnal. The MPPA or Expected

$$
\mathrm{MPPA}=\frac{\mathrm{nr}}{1+(\mathrm{n}-1) \mathrm{r}}(\mathrm{P}-\mathrm{A})
$$

Producing Ability (EPA) was computed on the basis of formula given by Lush (1945) as follows:

Where, $\mathrm{A}=$ Population mean

$\mathrm{N}=$ Total number of animals

$\mathrm{R}=$ Repeatability of lactation milk record

$\mathrm{P}=$ Milk yield in previous lactation

Thirty-two (32) Sahiwal cows were randomly divided into four (4) groups based on their MPPA and lactation number.
Their requirements were fulfilled by feeding concentrate mixture, green fodder (sorghum, maize, oats, sugar graze) and dry roughage (wheat straw) (NRC, 2001).

Individual herb was procured from local market after assessing their quality in consultation with ayurvedic practitioner and drug manufacturer. Each herb was pulverized separately. The Polyherbal mixture was prepared after mixing pulverized herbs in specific proportion.

Table 1: Experimental design of poly-herbal mixture supplementation during transition period

\begin{tabular}{|c|c|}
\hline Group & I \\
\hline $\begin{array}{c}\text { Control } \\
\left(\mathrm{T}_{0}\right)\end{array}$ & $\begin{array}{l}\text { Basal diet without supplementation (ICAR Feeding } \\
\text { standard) }\end{array}$ \\
\hline $\mathrm{T}_{1}$ & $\begin{array}{l}\text { Basal diet with poly-herbal mixture }(200 \mathrm{~g}) \text { - Shatavari, } \\
\text { Methi, Jeera }(50 \mathrm{~g} \text { each })+\text { Dalchini and Tulsi }(25 \mathrm{~g} \text { each })+ \\
\text { along with this mixture jaggery }(250 \mathrm{~g}) \text { were fed } 30 \text { days } \\
\text { before and } 60 \text { days after parturition. }\end{array}$ \\
\hline $\mathrm{T}_{2}$ & $\begin{array}{l}\text { Basal diet with poly-herbal (kadha) mixture }(150 \mathrm{~g}) \text { - } \\
\text { Ajwain, Fennel, Ginger, Black cardamom and Nigella sativa } \\
(25 \mathrm{~g} \text { each })+\text { Turmeric }(20 \mathrm{~g})+\text { Clove }(5 \mathrm{~g})+\text { along with } \\
\text { this polyherbal mixture Black salt }(25 \mathrm{~g})+\text { Jaggery }(250 \mathrm{~g}) \\
\text { were fed immediately after parturition for } 7 \text { days. }\end{array}$ \\
\hline $\mathrm{T}_{3}$ & $\begin{array}{l}\text { Basal diet with combination of } 200 \mathrm{~g} / \mathrm{d} \text { poly-herbal mixture } \\
\text { ( } 30 \text { days before and } 60 \text { days after parturition) }+150 \mathrm{~g} / \mathrm{d} \\
\text { Polyherbal (kadha) mixture (immediately after parturition } \\
\text { for } 7 \text { days) polyherbal mixture (delete it). }\end{array}$ \\
\hline
\end{tabular}

At the time of morning and evening milking on $1^{\text {st }}, 3^{\text {rd }}$ and $5^{\text {th }}$ day, colostrum yield was recorded by using electronic weighing balance. Colostrum somatic cells were estimated on $1^{\text {st }}, 3^{\text {rd }}$ and $5^{\text {th }}$ day by Lacto Scan Automatic Analyser (New Dairy Engineering and trading Co. Pvt. Ltd., Bulgaria) according to the manufacturer's protocol.

The data obtained in the present study were analysed by Two Way ANOVA (analysis of variance) and the significance of the difference between the mean values of various parameters was determined by Duncun Post-hoc test using SPSS (version 16.0) computer software.

\section{Results and Discussion}

Effect of poly-herbal mixture supplementation on colostrum yield ( $\mathrm{Kg} / \mathrm{day})$ of Sahiwal cows

The mean $\pm \mathrm{SE}$ values of colostrum yield ( $\mathrm{Kg} / \mathrm{day})$ were ranged from $3.35 \pm 0.37$ to $5.07 \pm 0.50$ in control $\left(\mathrm{T}_{0}\right), 4.42 \pm$ 0.51 to $6.35 \pm 0.50$ in $\mathrm{T}_{1}, 3.57 \pm 0.51$ to $5.92 \pm 0.52$ in $\mathrm{T}_{2}$ and $4.92 \pm 0.52$ to $7.35 \pm 0.47$ in $\mathrm{T}_{3}$ (Table 2 ). The overall mean \pm $\mathrm{SE}$ values of colostrum yield $(\mathrm{Kg} /$ day $)$ were $4.14 \pm 0.31,5.38$ $\pm 0.33,4.73 \pm 0.35$, and $6.02 \pm 0.35$ in $T_{0}, T_{1}, T_{2}$ and $T_{3}$ respectively. In the present study colostrum yield was differ significantly $(P \leq 0.05)$ between the periods in $\mathrm{T}_{0}, \mathrm{~T}_{1}$ and $\mathrm{T}_{2}$, but it was highly significant $(P \leq 0.01)$ for $\mathrm{T}_{3}$. Colostrum yield was not differ significantly at $1^{\text {st }}$ and $3^{\text {rd }}$ day however at $5^{\text {th }}$ day after calving it was higher $(P \leq 0.05)$ in $\mathrm{T}_{3}$ followed by $\mathrm{T}_{1}$, $\mathrm{T}_{2}$ and $\mathrm{T}_{0}$ groups of Sahiwal cows. The overall mean values of colostrum yield were also higher $(P \leq 0.05)$ in $\mathrm{T}_{3}$ followed by $\mathrm{T}_{1}, \mathrm{~T}_{2}$ and $\mathrm{T}_{0}$.

The results indicated that supplementation of poly-herbal mixture significantly increased colostrum yield as compared to control group. In agreement with our study Kumar et al. (2014) ${ }^{[12]}$ studied the effect of shatavari in KF cows and they were reported that, it increased $(P \leq 0.01)$ colostrum yield in shatavari supplemented groups than the control. The present study revealed that, polyherbal mixture improve the productive performance, it might be due to less stress and high DMI of Sahiwal cows during the transition period. In 
present experiment increase in colostrum yield might be due to the hormonal effect as Dadkhah and Yeganehzad (2011) ${ }^{[5]}$ also reported that supplementation of galactogogue herbal mixture in dairy cows had higher levels of hormone prolactin and insulin, which lead to increase milk production.

Table 2: Colostrum yield (Kg/day) of Sahiwal cows

\begin{tabular}{|c|c|c|c|c|}
\hline \multirow{2}{*}{ Days } & \multicolumn{4}{|c|}{ Colostrum yield (Kg/d) } \\
\cline { 2 - 5 } & $\mathbf{T}_{\mathbf{0}}$ & $\mathbf{T}_{\mathbf{1}}$ & $\mathbf{T}_{\mathbf{2}}$ & $\mathbf{T}_{\mathbf{3}}$ \\
\hline 1 & $3.35 \pm 0.37$ & $4.42 \pm 0.51$ & $3.57^{\mathrm{a}} \pm 0.51$ & $4.92^{\mathrm{a}} \pm 0.52$ \\
\hline 3 & $4.00 \pm 0.58$ & $5.35 \pm 0.54$ & $4.71^{\mathrm{ab}} \pm 0.51$ & $5.78^{\mathrm{a}} \pm 0.51$ \\
\hline 5 & $5.07^{\mathrm{w}} \pm 0.50$ & $6.35^{\mathrm{wx}} \pm 0.50$ & $5.92^{\mathrm{bwx}} \pm 0.52$ & $7.35^{\mathrm{b}^{\mathrm{b}_{\mathrm{x}}} \pm 0.47}$ \\
\hline
\end{tabular}

\begin{tabular}{|l|l|l|l|l|}
\hline Overall mean & $4.14^{\mathrm{w}} \pm 0.31$ & $5.38^{\mathrm{xy}} \pm 0.33$ & $4.73^{\mathrm{wx}} \pm 0.35$ & $6.02^{\mathrm{y}} \pm 0.35$ \\
\hline
\end{tabular}

Values with different superscripts abcd and wxyz differ significantly in a column (period wise) and in a row (group wise). Data represented as mean $\pm \mathrm{SE}\left({ }^{*} P \leq 0.01, P \leq 0.05\right)$

Effect of poly-herbal mixture supplementation on colostrum somatic cell count $(x \mathbf{1 0} / \mathrm{ml})$ of Sahiwal cows The overall mean \pm SE values of colostrum SCC were ranged from $2.39 \pm 0.36$ to $1.85 \pm 0.14$ in control $\left(\mathrm{T}_{0}\right), 2.03 \pm 0.35$ to $1.69 \pm 0.16$ in $\mathrm{T}_{1}, 2.43 \pm 0.29$ to $2.29 \pm 0.18$ in $\mathrm{T}_{2}$ and $2.21 \pm$ 0.30 to $1.61 \pm 0.17$ in $\mathrm{T}_{3}$ (Table 3 ). The overall mean $\pm \mathrm{SE}$ values of colostrum SCC were $2.10 \pm 0.14,1.85 \pm 0.14,2.29$ \pm 0.12 , and $1.86 \pm 0.15$ in $\mathrm{T}_{0}, \mathrm{~T}_{1}, \mathrm{~T}_{2}$ and $\mathrm{T}_{3}$ respectively. The values of colostrum SCC were not differing significantly between the periods. Colostrum SCC was not differ significantly at $1^{\text {st }}$ and $3^{\text {rd }}$ day but at $5^{\text {th }}$ day after calving it was lower $(P \leq 0.05)$ in $\mathrm{T}_{3}$ followed by $\mathrm{T}_{1}, \mathrm{~T}_{2}$ and $\mathrm{T}_{0}$ groups of Sahiwal cows. The overall mean values of colostrum SCC were also lower $(P \leq 0.05)$ in $\mathrm{T}_{3}$ followed by $\mathrm{T}_{1}, \mathrm{~T}_{2}$ and $\mathrm{T}_{0}$.

Table 3: Colostrum somatic cell count (x $\left.10^{5} / \mathrm{ml}\right)$ of Sahiwal cows

\begin{tabular}{|c|c|c|c|c|}
\hline \multirow{2}{*}{ Days } & \multicolumn{4}{|c|}{ Colostrum somatic cell count $(\times \mathbf{1 0}$ / $\mathbf{m l})$} \\
\cline { 2 - 5 } & $\mathbf{T}_{\mathbf{0}}$ & $\mathbf{T}_{\mathbf{1}}$ & $\mathbf{T}_{\mathbf{2}}$ & $\mathbf{T}_{\mathbf{3}}$ \\
\hline 1 & $2.39 \pm 0.36$ & $2.03 \pm 0.35$ & $2.43 \pm 0.29$ & $2.21 \pm 0.30$ \\
\hline 3 & $2.06 \pm 0.14$ & $1.82 \pm 0.23$ & $2.14 \pm 0.14$ & $1.75 \pm 0.26$ \\
\hline 5 & $1.85^{\mathrm{w} x} \pm 0.14$ & $1.69^{\mathrm{w}} \pm 0.16$ & $2.29^{\mathrm{x}} \pm 0.18$ & $1.61^{\mathrm{w}} \pm 0.17$ \\
\hline Overall mean & $2.10 \pm 0.14$ & $1.85 \pm 0.14$ & $2.29 \pm 0.12$ & $1.86 \pm 0.15$ \\
\hline
\end{tabular}
Values with different superscripts abcd and wxyz differ significantly in a column (period wise) and in a row (group wise). Data represented as mean $\pm \mathrm{SE}(P \leq 0.05)$

SCC increases of greater than 2,00,000 cells/ml have been observed in cow milk as a result of bacterial infection and it affect quality and quantity of milk (Bramley, 1992; Harmon, 1994) ${ }^{[2,9]}$. Colostrum SCC was within the range in all supplemented groups except control group of Sahiwal cows. Similarly, Kumari, (2015) ${ }^{[13]}$ reported that, SCC was lower $(\mathrm{P} \geq 0.05)$ in the polyherbal supplemented groups of Karan Fries cows than the control. The results of the present study were also in agreement with the Hashemzadeh-Cigari et al. (2014) [10] who reported that the supplementation of phytobiotics-rich herbal mixture seems to be an effective strategy to enhance production performance and lower SCC, particularly in cows having high SCC levels in the milk. In relation the present study Sharma et al., $2014^{[16]}$ reported that polyherbal supplementation at the rate of $200-250 \mathrm{mg} / \mathrm{kg}$ body weight reduced peri-parturient stress and improved immunity and udder health.

\section{Conclusions}

Poly-herbal supplementation containing the combination of $200 \mathrm{~g}$ polyherbal mixture -Shatavari, Methi and Jeera (50 g each) + Dalchini and Tulsi (25 g each) along with this mixture jaggery $(250 \mathrm{~g})$ were fed 30 days before and 60 days after parturition and $150 \mathrm{~g}$ polyherbal (kadha) mixture - Ajwain, Fennel, Ginger, Black cardamom and Nigella sativa (25 g each) + Turmeric $(20 \mathrm{~g})+$ Clove $(5 \mathrm{~g})+$ along with this polyherbal mixture Black salt (25 g) + Jaggery (250 g) were fed immediately after parturition for 7 days reduced periparturient stress improved colostrum production and udder health of Sahiwal cows.

\section{References}

1. $19^{\text {th }}$ Livestock Census. All India Report, Department of Animal Husbandry, Dairying and Fisheries. Ministry of Animal Husbandry, Dairying and Fisheries, Ministry of Agriculture, Government of India, 2012.

2. Bramley AJ, Dodd FH, Mein GA and Bramley JA. Milk hygiene and machine milking. Machine Milking and Lactation, 1992, 343-372.

3. Brugalli I, Alimentação alternativa: a utilização de fitoterápicos ou nutracêuticos como moduladores da imunidade e desempenho animal. Simpósio sobre manejo e nutrição de aves e suínos, 2003, 1.

4. Chauhan RS. Immunomodulation using cowpathy. In: IV SIIP Convention and National Symposium on "Immuno biotechnology" at Chennai on Feb. 2007; 25-27:75-80.

5. Dadkhah MA, Yeganehzad M. The effects of extracts of plants (Medicago sativa, Trigonella foenum and Carum carvi) on milk production in dairy cows. Advances in Environmental Biology. 2011; 5(10):3129-3134.

6. Dorman HJD, Deans SG. Antimicrobial agents from plants: antibacterial activity of plant volatile oils. Journal of applied microbiology. 2000; 88(2):308-316.

7. Drackley JK. Biology of dairy cows during the transition period: The final frontier? Journal of dairy science. 1999; 82(11):2259-2273.

8. Govt. of Pakistan, Livestock census. Agricultural Census Organization, Statistics Division, Lahore, 2006.

9. Harmon RJ. Physiology of mastitis and factors affecting somatic cell counts. Journal of dairy science. 1994; 77(7):2103-2112.

10. Hashemzadeh-Cigari F, Khorvash M, Ghorbani GR, Kadivar M, Riasi A, Zebeli Q. Effects of supplementation with a phytobiotics-rich herbal mixture on performance, udder health, and metabolic status of Holstein cows with various levels of milk somatic cell counts. J Dairy Sci. 2014; 97(12):7487-97.

11. Hui YH. Oleoresins and essential oils. Bailey's industrial oil and fat products. New York: Wiley-Interscience Publication. 1996; 6:145-153.

12. Kumar S, Mehla RK, Singh M. Effect of Shatavari (Asparagus racemosus) on milk production and Immunemodulation in Karan Fries crossbred cows. Indian J. of Traditional Knowledge. 2014; 13(2):404-408.

13. Kumari A. Supplementation of Polyherb-Mineral Mixture asimmunomodulator During Transition Period in Crossbred Cows. PhD Thesis, NDRI, Karnal, 2015.

14. Leroy P, Marchot P. The resistance to dermatophilosis of Dinka cattle breed, Dinka crossbred and Boran, Friesian, Jersey, Sahiwal crossbreds, 1987.

15. Pervez A, Response of broiler chicks to different feed additives (Doctoral dissertation, M. Sc Thesis NWFP Agricultural University, Peshawar, Pakistan), 1992.

16. Sharma A, Kimothi SP, Singh Y, Bishisth R. Effect of polyherbal preparation supplementation on immunity and udder health of periparturient Karan-Fries crossbred dairy 
cows, Journal of Applied Animal Research. 2014;

42(2):217-221. 